\title{
ANALISIS KEMAMPUAN SOFT SKILLS SISWA KELAS XI SMK FUTUHIYYAH MRANGGEN DEMAK
}

\author{
Muhammad Zammi ${ }^{1}$, Kholifatul Khoiriyyah ${ }^{2}$ \\ ${ }^{1}$ UIN Walisongo Semarang, ${ }^{2}$ SMK Futuhiyyah Mranggen Demak
}

\begin{abstract}
Abstrak
Pembelajaran di SMK seyogyanya dapat membekali keterampilan kepada siswa terutama kemampuan soft skills untuk terjun di dunia kerja, sehingga pembelajaran lebih bermakna dan bermanfaat bagi siswa. Desain pembelajaran dengan pendekatan chemoenterpreneurship seharusnya menumbuhkan kemampuan soft skills siswa, sehingga penelitian ini bertujuan memetakan kemampuan soft skills siswa secara deskriptif kuantitatif. Teknik pengambilan data menggunakan non tes berupa lembar observasi soft skills. Subyek penelitian ini adalah siswa kelas XI SMK Futuhiyyah Mranggen Demak. Hasil penelitian menunjukkan kemampuan soft skills meliputi: memecahkan masalah dengan kriteria tinggi, berkomunikasi dengan kriteria tinggi, kepemimpinan dengan kriteria tinggi, berpikir kreatif dengan kriteria tinggi dan kerja tim dengan kriteria tinggi.
\end{abstract}

Kata kunci: chemoenterpreneurship, soft skills

\begin{abstract}
Learning in SMK should be able to equip the skills to students, especially soft skills skills to work in the world of work, so that learning is more meaningful and useful for students. The design of learning with chemoenterpreneurship approach should foster the soft skills of the students, so this research aims to map the students' soft skills ability in quantitative descriptive. Technique of taking data using non test in the form of soft skill observation sheet. The study was conducted on students of class XI SMK Futuhiyyah Mranggen Demak. The results show that soft skills include: solving problems with high criteria, communicating with high criteria, high criteria leadership, creative thinking with high criteria and teamwork with high criteria.
\end{abstract}

Keywords: chemoenterpreneurship, soft skills

\section{PENDAHULUAN}

Pendidikan memiliki peran penting untuk menunjang kehidupan manusia agar dapat bertahan hidup untuk masa depan, sehingga pendidikan harus sesuai dengan perkembangan zaman dan memiliki manfaat dalam memenuhi kebutuhan manusia.

UIN Walisongo Semarang

Email: zammi@walisongo.ac.id
(C2018 Universitas Islam Negeri Walisongo 154

ISSN: 2088-7868, e-ISSN 2502-5708 
Menurut UUSPN No. 20 tahun 2003 menyatakan bahwa pendidikan adalah usaha sadar dan terencana untuk mewujudkan suasana belajar dan proses pembelajaran agar peserta didik secara aktif mengembangkan potensi dirinya. Untuk mencapai tujuan tersebut maka pendidikan sudah seharusnya diarahkan untuk membekali siswa dengan keterampilan-keterampilan dasar yang harus dimiliki untuk menunjang kehidupannya pada setiap mata pelajaran salah satunya kimia, sesuai pendapat Cahyono (2017) siswa perlu dibekali keterampilan pemecahan masalah, berfikir kreatif, berfikir kritis dan kemampuan komunikasi yang baik akan meningkatkan daya tahan/saing seseorang dalam berkompetisi sehingga menjadi yang terunggul dalam pembelajaranya. Melalui belajar materi kimia yang mempelajari fenomena yang sangat dekat dengan kehidupan manusia diharapkan pembelajaranat lebih bermakna (Sa'adah dan Supartono, 2013).

Salah satu pendekatan pembelajaran yang bermakna bagi siswa SMK adalah chemoentrepreneurship (CEP). CEP merupakan pendekatan pembelajaran kimia yang tidak hanya berorientasi pada penguasaan materi (subject-matter oriented), tetapi lebih menekankan pada penerapan konsep dengan mengaitkan fenomena di sekitar kehidupan (life-skill oriented) sehingga selain menguasai konsep pendekatan ini memungkinkan siswa dapat mempelajari proses pengolahan suatu bahan menjadi produk bermanfaat, bernilai ekonomi, dan memotivasi siswa untuk berwirausaha, pembelajaran kimia menjadi menarik, menyenangkan, dan lebih bermakna (Supartono, 2005). chemoentrepreneurship (CEP) juga dapat meningkatkan kemampuan life skill siswa (Kusuma et al., 2009) dan implementasi modul berorientasi CEP berbasis keunggulan lokal efektif meningkatkan kemampun soft skill siswa (Diniy, 2013). Pendekatan CEP selaras dengan karakteristik pembelajaran di SMK karena membuat pembelajaran kimia lebih aplikatif dan membekali soft skill siswa seperti keterampilan pemecahan masalah, berfikir kreatif, berfikir kritis dan kemampuan komunikasi yang baik. Kemampuan soft skill sangat penting bagi siswa SMK karena 86\% lulusan SMK terserap dalam dunia kerja sehingga kemampuan komunikasi dan kerja sama tim (soft skill) lebih bermanfaat untuk karir siswa di masa depan (Bolyston, 2003). Berglund (2006) menambahkan bahwa soft skill sangat bermanfaat dalam dunia industri khususnya sifat kreatif sehingga lulusan SMK lebih mampu bertahan walaupun semakin bertambahnya persaingan industri. Dan pendapat beberapa ahli bahwa seseorang yang mempunyai ketrampilan berfikir kritis tinggi dan kemampuan komunikasi yang baik akan mudah menyesuaikan 
perubahan kondisi dan dihargai baik dalam konteks akademik dan dunia kerja (Cahyono, 2017).

Soft skills memiliki peranan penting dalam pendidikan SMK karena dalam soft skills mengandung aspek karakter kerja yang diperlukan sebagai perlengkapan kompetensi yang harus dikuasai oleh siswa. Soft skills juga dapat meningkatkan rasa percaya diri siswa (Al Mamun: 2012). Soft skills memungkinkan siswa dengan kerangka kerja konseptual dan praktis yang kuat untuk membangun, mengembangkan dan mengelola tim sehingga dapat meningkatkan prospek karir kerja mereka di masa yang akan datang. Soft skills diberikan untuk membentuk sikap siswa, nilai-nilai, keyakinan, motivasi, keinginan, perasaan, keinginan untuk belajar, kemauan untuk berbagi dan menciptakan ide-ide baru, orientasi tujuan, fleksibilitas, persuasi, pemikiran futuristik, perbandingan, diplomasi dan berbagai keterampilan komunikasi, sopan santun dan tata krama sehingga mereka akan mampu bertahan dalam keadaan apa pun dan memiliki rasa tanggung jawab yang lebih besar (Rani, 2010). Soft skill yang penting untuk dikembangkan dalam dunia kerja antara lain insiatif, etika, berpikir kritis, kemauan belajar, komitmen, motivasi, semangat, dapat diandalkan, komunikasi lisan, kreatif, kemampuan analisis, dapat mengatsi stress, menajemen diri, menyelesaikkan persoalan, dapat meringkas, berkooperasi, fleksibel, kerja sama tim, mandiri, mendengarkan, tangguh, beragumen logis, dan menajemen waktu (Doe, 2001).

Analisis kemampuan soft skill siswa yang diamati dalam penelitian ini adalah Soft skills yang diamati adalah kemampuan memecahkan masalah, kemampuan berkomunikasi, keterampilan kepemimpinan, berpikir kreatif, dan kemampuan kerja tim yang didapatkan dengan menggunakan lembar observasi sangat penting dilakukan untuk mengetahui sejauh mana soft skill siswa. Sehingga dapat dijadikan bahan pertimbangan dalam dalam menentukan metode dan pendekatan yang sesuai dengan karakteristik siswa SMK.

\section{METODE PENELITIAN}

Jenis penelitian ini adalah deskriptif kuantitatif dengan menganalisis kemampuan soft skill siswa kelas XI SMK Futuhiyyah Mranggen Demak yang berjumlah 28 siswa. Variabel yang terlibat dalam penelitian ini adalah kemampuan soft skill siswa. Observasi dilakukan untuk mendapatkan data tentang kemampuan soft skill siswa selama kegiatan 
pembelajaran. Aspek penilaian dan teknik penskoran untuk perangkat pembelajaran tercantum pada lembar observasi tersebut.

Analisis data dilakukan dengan analisis deskriptif kuantitatif pada kemampuan soft skill siswa. Soft skills yang diamati dalam penelitian ini yaitu kemampuan memecahkan masalah, kemampuan berkomunikasi, keterampilan kepemimpinan, berpikir kreatif, dan kemampuan kerja tim. Indikator yang diamati dalam memecahkan masalah yaitu mengidentifikasi masalah, menganalisis masalah dan memberi solusi penyelesaian masalah (Cahyono, 2015). Indikator kemampuan komunikasi meliputi mampu membaca informasi dan menginterpretasikannya, dan berbicara dengan jelas dan mudah dimengerti. Indikator keterampilan kepemimpinan meliputi kemampuan interpersonal, memanfaatkan waktu dengan baik dan membagi tugas tim secara proporsional. Indikator berfikir kritis meliputi menyelesaikan suatu masalah dengan tujuan tertentu, menganalisis, menggeneralisasikan, mengorganisasikan ide berdasarkan fakta/informasi yang ada, dan menarik kesimpulan dalam menyelesaikan masalah tersebut secara sistematik dengan argumen yang benar (Cahyono, 2015). Indikator berpikir kreatif meliputi memiliki gagasan orisinil dan mampu melihat masalah dari berbagai sudut pandang. Sedangkan indikator kemampuan kerja tim meliputi kontribusi terhadap tim, tanggung jawab tim, dominasi kelompok dan toleransi dalam kelompok.

. Kemampuan soft skill diklasifikasikan dengan skala liket lima mulai dari sangat rendah, rendah, cukup, tinggi dan sangat tinggi sedangkan untuk tiap item pertanyaan diberikan skor dengan rentang 1- 4. Untuk mengetahui persentase deskripsi kemampuan soft skill siswa digunakan rumus N-Gain sebagai berikut:

$$
A=\frac{n}{N} \times 100 \%
$$

Keterangan: $\mathrm{A} \quad=$ persentase kemampuan soft skills

$\mathrm{n} \quad=$ jumlah skor yang diperoleh

$\mathrm{N} \quad=$ jumlah skor maksimal (Trianto, 2010)

Kriteria deskriptif persentase kemampuan soft skill (A) dalam pembelajaran yaitu:

$$
\begin{array}{ll}
85 \% \leq \mathrm{A} \leq 100 \% & \text { sangat tinggi } \\
68 \% \leq \mathrm{A}<85 \% & \text { tinggi } \\
52 \% \leq \mathrm{A}<68 \% & \text { cukup } \\
36 \% \leq \mathrm{A}<52 \% & \text { rendah } \\
20 \% \leq \mathrm{A}<36 \% & \text { sangat rendah }
\end{array}
$$




\section{HASIL DAN PEMBAHASAN}

Selama proses pembelajaran berlangsung soft skills siswa yang muncul diamati untuk memperoleh data soft skills siswa. Soft skills siswa yang diamati meliputi kemampuan memecahkan masalah, kemampuan berkomunikasi, keterampilan kepemimpinan, berpikir kreatif, kemampuan kerja tim. Hasil analisis presentase perolehan pada tiap aspek soft skills siswa disajikan pada Gambar 1.

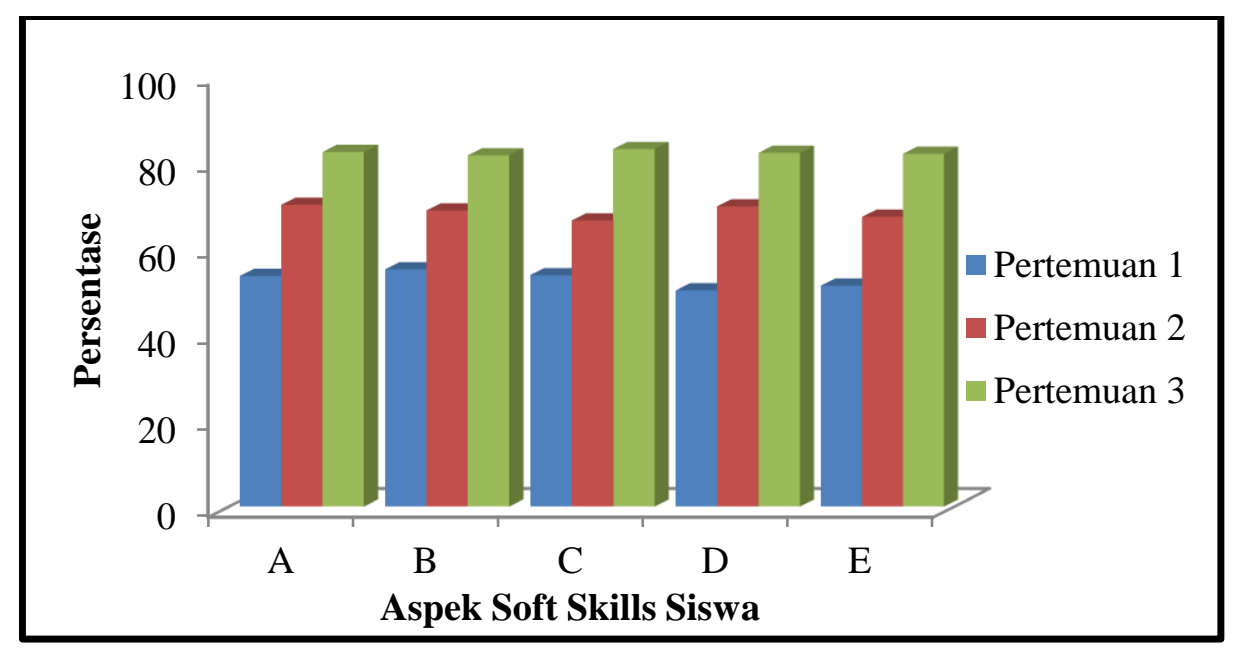

Gambar 1 Persentase Tiap Aspek Soft Skills Siswa

Keterangan: $\mathrm{A}=$ Memecahkan masalah, $\mathrm{B}=$ Berkomunikasi, $\mathrm{C}=$ Kepemimpinan, $\mathrm{D}=$ Berpikir kreatif, $\mathrm{E}=$ Kerja tim

Dari Gambar 1 dapat dilihat bahwa Persentase Tiap Aspek Soft Skills Siswa yang terdiri dari kemampuan memecahkan masalah, berkomunikasi, kepemimpinan, berfikir kreatif dan kerja tim siswa pada tiap pertmuan selalu mengalami peningkatan yang cukup signifikan. Untuk memperjelas hasil penelitian selanjutnya akan dibahas untuk tiap kemampuan.

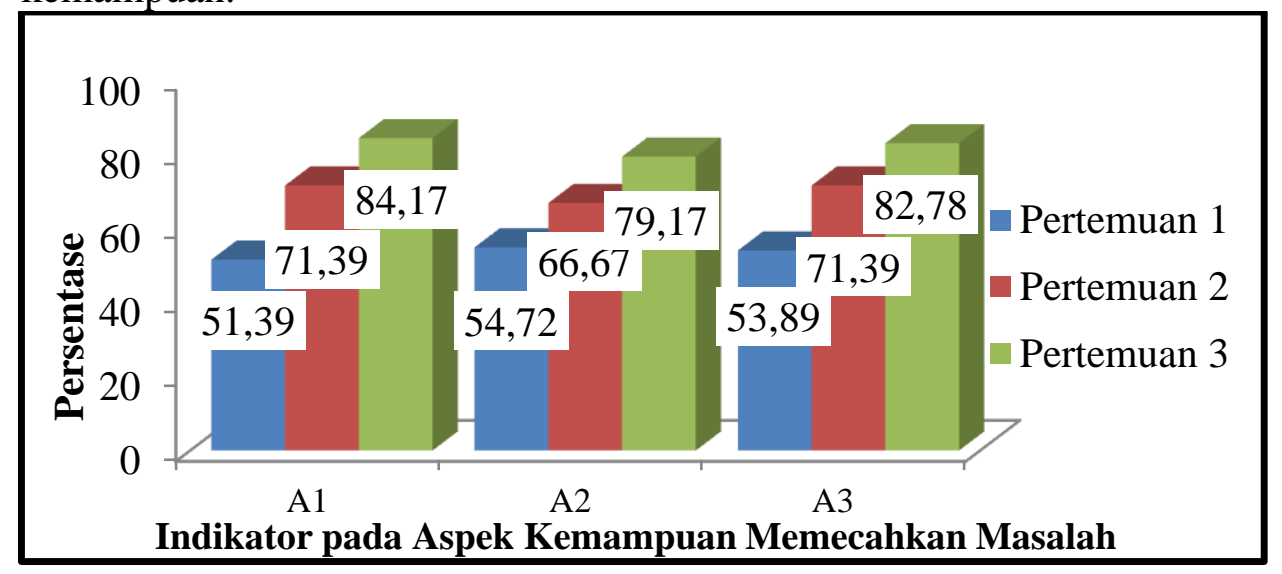

Gambar 2 Persentase Indikator pada Aspek Kemampuan Memecahkan Masalah Keterangan : A1 $=$ Mengidentifikasi, A2 = Menganalisis, A3 = Memberi solusi 


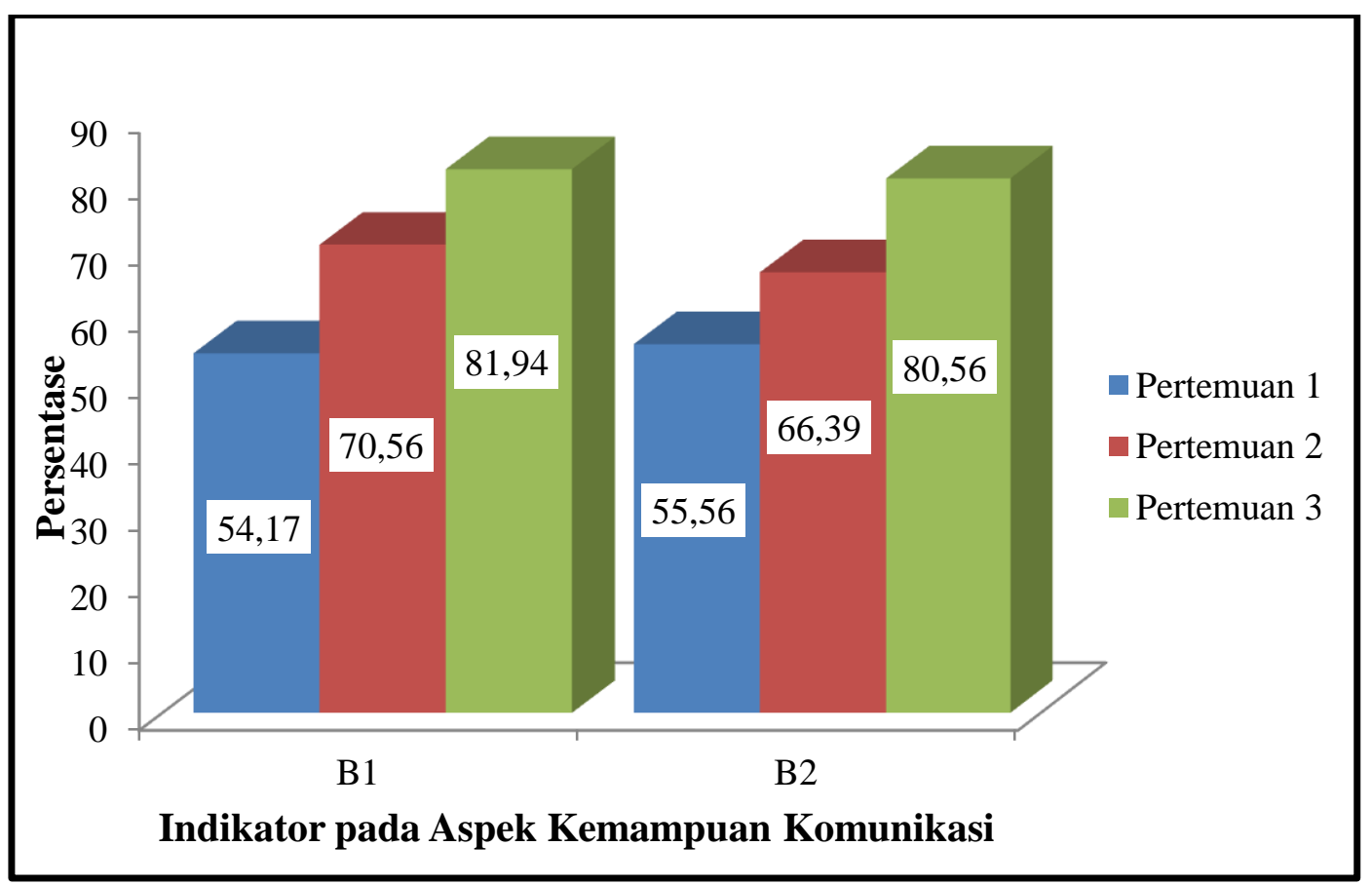

Gambar 3 Persentase Indikator pada Aspek Kemampuan Komunikasi

Keterangan : B1= Membaca informasi dan menginterpretasikannya, B2 = Berbicara dengan jelas dan mudah dimengerti

Persentase indikator pada aspek kemampuan memecahkan masalah yang ditinjau dari indikator mengidentifikasi, menganalisis, dan memberikan solusi (Cahyono, 2015) disajikan pada Gambar 2. Dari gambar dapat dilihat adanya peningkatan skor persentase pada tiap indikator kemampuan pemecahan masalah yang cukup signifikan sehingga menghasilkan peningkatan pada jumlah persentase pada pembelajaran pertama yang hanya 52,35\% yang masuk kriteria cukup menjadi $81,2 \%$ sehingga pada kemampuan pemecahan masalah masuk kriteria tinggi setelah diberikan perlakuan. Sedangkan peningkatan kemampuan komunikasi dapat dilihat dari gambar 3 yang menggambarkan bahwa setiap indikator kemampuan komunikasi yaitu membaca informasi dan menginterprestasikanya dan berbicara dengan jelas dan mudah dimengerti mengalami peningkatan dari tiap pertemuan. Peningkatan pada jumlah persentase kemampuan komunikasi pada pembelajaran pertama yang hanya $55 \%$ yang masuk kriteria cukup menjadi 81,4 \% sehingga pada kemampuan komunikasi masuk kriteria tinggi setelah diberikan perlakuan. 


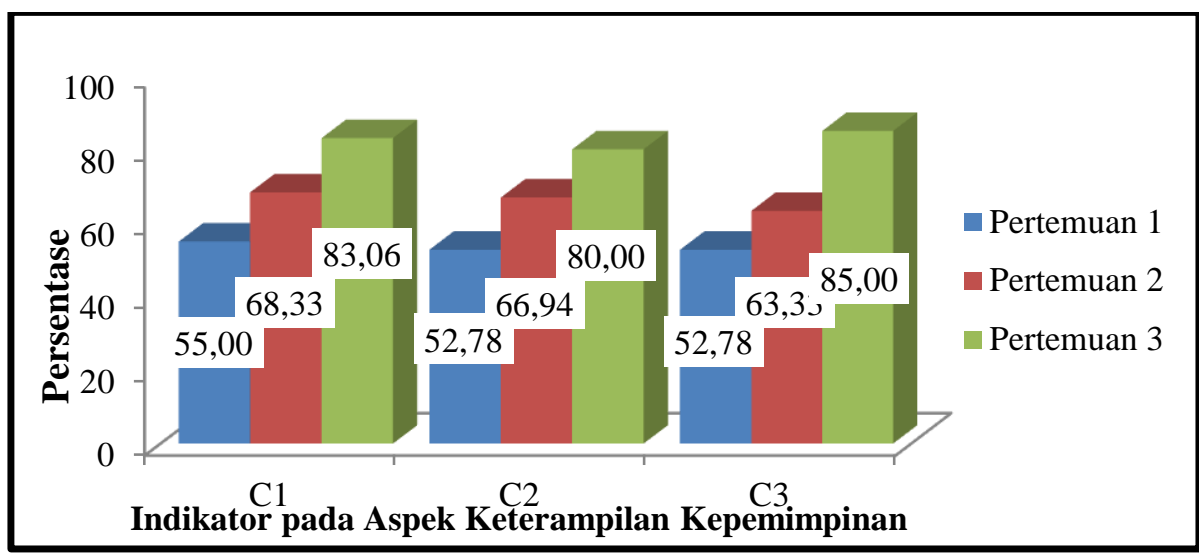

Gambar 4 Persentase Indikator pada Aspek Keterampilan

Keterangan : $\mathrm{C} 1=$ Kemampuan interpersonal, $\mathrm{C} 2=$ Memanfaatkan waktu dengan baik, $\mathrm{C} 3=$ Membagi tugas tim secara proporsional

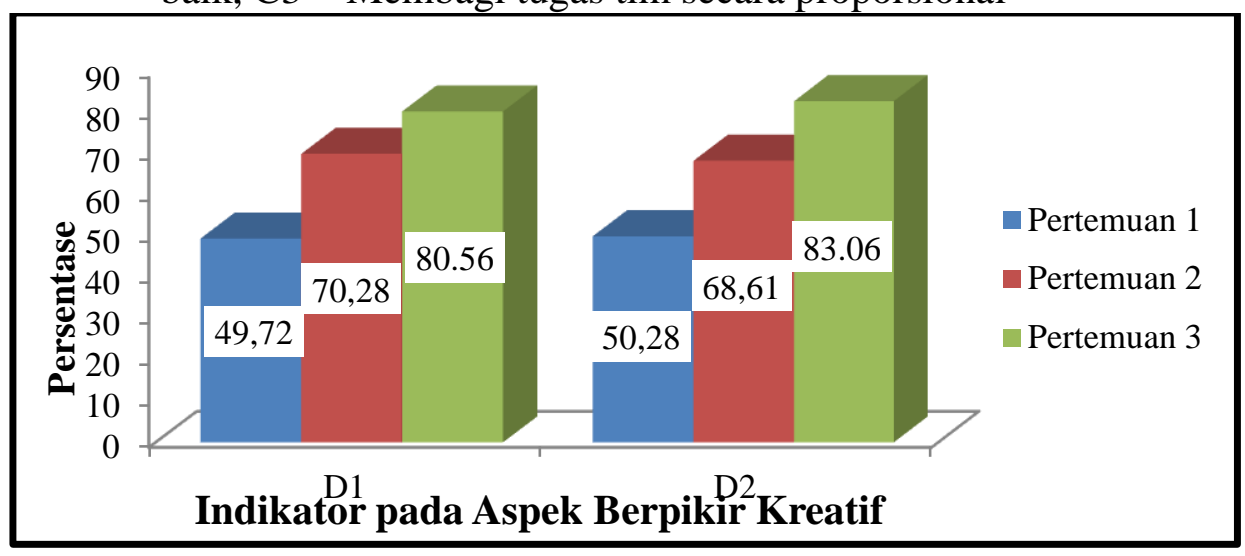

Gambar 5 Persentase Indikator pada Aspek Berpikir Kreatif

Keterangan : D1 = Memiliki gagasan orisinil, D2 = Mampu melihat masalah dari berbagai sudut pandang

Keterampilan kepemimpinan ditinjau dari indikator kemampuan interpersonal, memanfaatkan waktu dengan baik dan membagi tugas tim secara proposional mengalami peningkatan yang signifikan hal tersebut dapat dilihat pada gambar grafik 4 . Peningkatan pada jumlah persentase keterampilan kepemimpinan pada pembelajaran pertama yang hanya 53,5\% yang masuk kriteria cukup menjadi 82,2\% sehingga pada keterampilan kepemimpinan masuk kriteria tinggi setelah diberikan perlakuan. Sedangkan pada kemampuan berfikir kreatif yang diobsevasi melalui indikator memiliki gagasan orisinil dan mampu melihat masalah dari berbagai sudut pandang mengalami peningkatan yang signifikan pada tiap indikatornya jika dibandingkan pada tiap tahap pembelajaran hal tersebut dapat dilihat pada gambar 5. Peningkatan pada jumlah persentase kemampuan berfikir kreatif pada pembelajaran pertama yang hanya $50 \%$ yang masuk kriteria cukup menjadi $82 \%$ sehingga pada kemampuan berfikir kreatif masuk kriteria tinggi setelah diberikan perlakuan. 


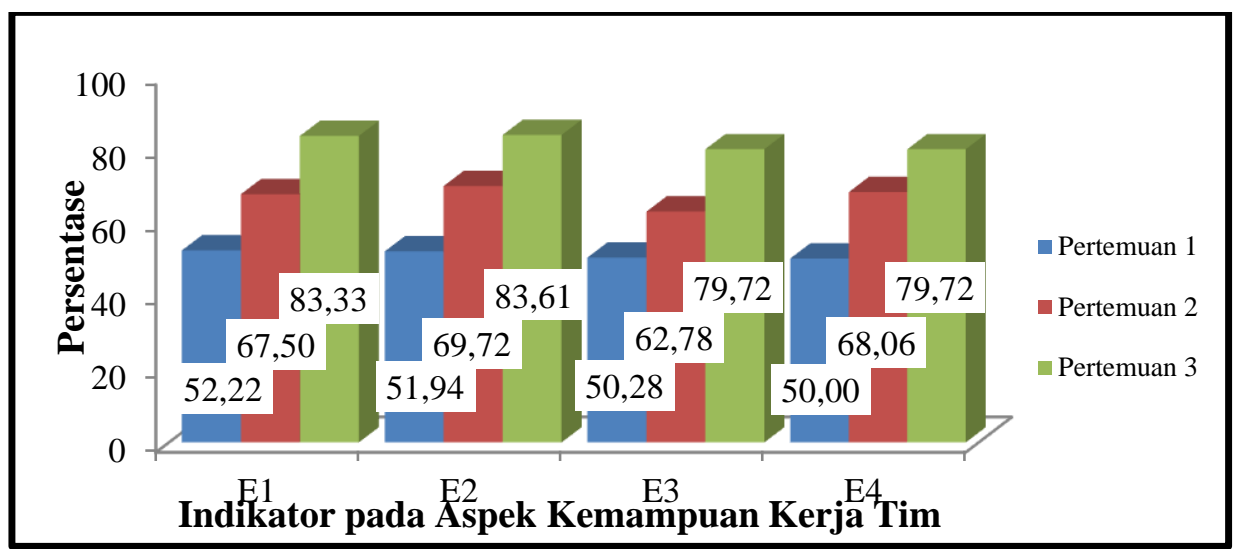

Gambar 6 Persentase Indikator pada Aspek Kemampuan Kerja Tim Keterangan $:$ E1 = Kontribusi, E2 = Tanggung jawab, E3 = Dominasi, E4 = Toleransi

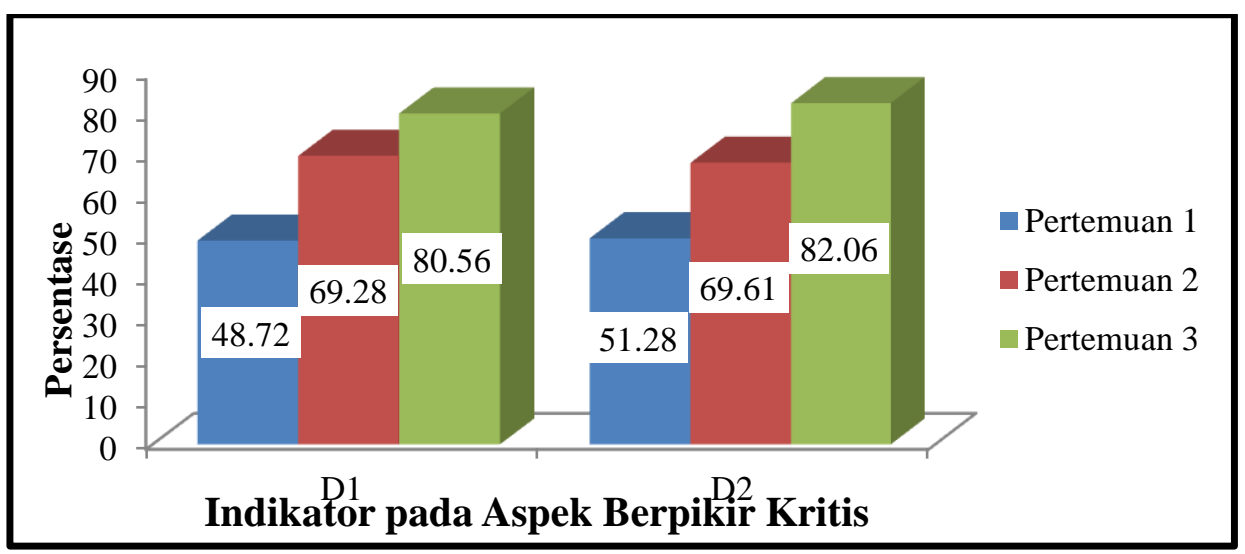

Gambar 7 Persentase Indikator pada Aspek Berpikir Kritis

Keterangan: D1= Menyelesaikan suatu masalah dengan tujuan tertentu, menganalisis, menggeneralisasikan, mengorganisasikan ide berdasarkan fakta/informasi yang ada, D2 = menarik kesimpulan dalam menyelesaikan masalah tersebut secara sistematik dengan argumen yang benar

Kemampuan kerja tim ditinjau dari indikator kontribusi, tanggung jawab, dominasi dan toleransi mengalami peningkatan yang signifikan hal tersebut dapat dilihat pada gambar grafik 4. Peningkatan pada jumlah persentase keterampilan kepemimpinan pada pembelajaran pertama yang hanya $51 \%$ yang masuk kriteria cukup menjadi $81 \%$ sehingga pada kemampuan kerja tim masuk kriteria tinggi setelah diberikan perlakuan. Sedangkan pada kemampuan berfikir kritis yang diobsevasi melalui indikator menyelesaikan suatu masalah dengan tujuan tertentu, menganalisis, menggeneralisasikan, mengorganisasikan ide berdasarkan fakta/informasi yang ada, dan menarik kesimpulan dalam menyelesaikan masalah tersebut secara sistematik dengan argumen yang benar mengalami peningkatan yang signifikan pada tiap indikatornya jika dibandingkan pada tiap tahap pembelajaran hal tersebut dapat dilihat pada gambar 7. Peningkatan pada jumlah persentase kemampuan berfikir kritis pada pembelajaran pertama yang hanya $49 \%$ 
yang masuk kriteria cukup menjadi $81 \%$ sehingga pada kemampuan berfikir kritis masuk kriteria tinggi setelah diberikan perlakuan.

Berdasarkan ketercapaian indikator masing-masing soft skills di atas, tiap aspek soft skills mengalami peningkatan. Hal ini menunjukkan bahwa implementasi perangkat pembelajaran chemoentrepreneurship efektif meningkatkan soft skills siswa SMK. Hasil ini sesuai dengan penelitian Noviayanti (2013), bahwa perangkat pembelajaran berorientasi chemoentrepreneurship dapat meningkatkan minat wirausaha dan soft skill siswa serta siswa merespon positif pembelajaran dengan perangkat pembelajaran CEP.

\section{SIMPULAN}

Implementasi perangkat pembelajaran chemoentrepreneurship CEP efektif untuk meningkatkan soft skills siswa SMK hal tersebut dapat dilihat dari adanya peningkatan persentase rata-rata dari 52,56\% menjadi $81,88 \%$. Peningkatan tiap indicator dapat dilihat dari peningkatan persentase pada pembelajaran pertama yang hanya 52,35\% yang masuk kriteria cukup menjadi 81,2 \% sehingga pada kemampuan pemecahan masalah masuk kriteria tinggi, peningkatan persentase kemampuan komunikasi pada pembelajaran pertama yang hanya $55 \%$ yang masuk kriteria cukup menjadi $81,4 \%$ sehingga pada kemampuan komunikasi masuk kriteria tinggi, peningkatan persentase keterampilan kepemimpinan pada pembelajaran pertama yang hanya 53,5\% yang masuk kriteria cukup menjadi $82,2 \%$ sehingga pada keterampilan kepemimpinan masuk kriteria tinggi.

Peningkatan persentase kemampuan berfikir kreatif pada pembelajaran pertama yang hanya $50 \%$ yang masuk kriteria cukup menjadi $82 \%$ sehingga pada kemampuan berfikir kreatif masuk kriteria tinggi, peningkatan persentase keterampilan kepemimpinan pada pembelajaran pertama yang hanya $51 \%$ yang masuk kriteria cukup menjadi $81 \%$ sehingga pada kemampuan kerja tim masuk kriteria tinggi, dan peningkatan persentase kemampuan berfikir kritis pada pembelajaran pertama yang hanya $49 \%$ yang masuk kriteria cukup menjadi $81 \%$ sehingga pada kemampuan berfikir kritis masuk kriteria tinggi. Penelitian lanjutan untuk menguji metode chemoentrepreneurship (CEP) perlu dilakukan dengan mengubah metode pengambilan data pada kemampuan berfikir kreatif, pemecahan masalah, dan berfikir kritis melalui metode tes supaya lebih mendekati hasil yang diinginkan. 


\section{DAFTAR PUSTAKA}

Al Mamun, A. 2012. "The Soft Skills Education for the Vocational Graduate: Value as Work Readiness Skills". British Journal of Education, Society \& Behavioural Science, Volume 2 No.4. Page 326-338.

Berglund, H. 2006. "Creativity Among Entrepreneurship Students: Comparing Engineering and Business Education”. Int. J. Cont. Engineering Education and Lifelong Learning, Volume 16 Hal 5. Page 366-379.

Bolyston, T. D. and Wang, T. 2003. "Integration of Team-Building Skills into Food Chemistry Team Research Projects". Journal of Food Science Education, Volume 2. Page 18-24.

Cahyono, Budi. 2017. “Analisis Ketrampilan Berfikir Kritis Dalam Memecahkan Masalah Ditinjau Perbedaan Gender". Jurnal Phenomenon: Jurnal Pendidikan MIPA, $\quad$ Volume $\quad 8 \quad$ No $1 . \quad$ Hal http://journal.upgris.ac.id/index.php/aksioma/issue/view/198

Cahyono, Budi. 2015. “ Korelasi Pemecahan Masalah dan Indikator Berfikir Kritis”. Jurnal Phenomenon: Jurnal Pendidikan MIPA, Volume 5 No 1. Hal 15-24. http://journal.walisongo.ac.id/index.php/Phenomenon/issue/view/32

Diniy, H. 2013. "Penyusuanan Modul Materi Koloid Berorientasi Chemoenterpreneurship Berbasis Keunggulan Lokal Untuk Mengembangkan Soft Skill Siswa". Tesis. Semarang: Program Pascasarjana Unnes.

Doe, J. 2001. The Performance $D N A^{T M}$ System: Identifying, Prioritizing and Calibrating Performance Criteria Personal Soft Skills Indicator. Canada: Excel Group Development.

Kusuma, E., Sukirno, dan Kurniati. I. 2009. "Penggunaan Pendekatan ChemoEntrepreneurship Berorientasi Green Chemistry Untuk Meningkatkan Kemampuan Life Skill Siswa SMA".Jurnal Inovasi Pendidikan Kimia, Volume 3 No. 1. Hal 366-372.

Noviayanti, D. 2013. "Pengembangan Perangkat Pembelajaran Hidrokarbon Dan Minyak Bumi Berorientasi Chemoenterpreneurship Untuk Meningkatkan Soft Skill Siswa Dan Minat Wirausaha".Tesis. Semarang: Program Pascasarjana Unnes

Rani, S.M.E. 2010."Need And Importance Of Soft Skills In Students".Associate Professor in English, Sri Sarada College for Women, Volume 2.Page 1-7.

Sa'adah dan Supartono. 2013. Penggunaan Pendekatan Chemoentrepreneurship Pada Materi Larutan Penyangga Untuk Meningkatkan Life Skill Siswa.Chemistry in Education, Volume 2 No. 1. Hal 111-117.

Supartono. 2005. "Chemo-Entreprenuership (CEP) Sebagai Pendekatan Pembelajaran 
Kimia Yang Inovatif dan Kreatif'. Makalah. Prosiding Seminar Nasional Matematika dan Ilmu Pengetahuan Alam. Semarang.

Undang-undang Republik Indonesia Nomor 20 Tahun 2003 tentang Sistem Pendidikan Nasional. 2003. Jakarta. 